Vesna Milićević1, Bojan Ilić², Adam Sofronijević ${ }^{3}$

1,2 University of Belgrade, Faculty of Organizational Sciences

${ }^{3}$ University of Belgrade, University Library "Svetozar Marković"

\title{
Business Aspects of Creative Industries from a Global Perspective
}

UDK: $338.46: 008 ; 005.336 .1$

DOI: 10.7595/management.fon.2013.0003

\begin{abstract}
The paper deals with business and managerial aspects of global creative industries. The focus is on achieving competitive advantages in a creative market. The diversified nature of creative industries is analysed by considering growth opportunities at the beginning of the 21st century. Furthermore, the concept of a creative economy is defined in the context of its relations to culture, management and information and communication technologies. The business activities of creative enterprises and professionals presented in this paper suggest the challenges for the development of new business models in creative industries in the future.
\end{abstract}

Keywords: creative industries, business models, creative industries market, management, business success, experience economy, globalization of business

\section{Introduction}

The beginning of the $21^{\text {st }}$ century is characterized by the "new economy" which entails the affirmation of intangible resources in creating value, especially culture, communication, managerial abilities, creativity, as well as the importance of information and communication technologies (ICT) and digitalization of business. The Internet has influenced the change in business models, as well as lifestyle by generating the creation of a cyber-culture. Further expansion of business activities related to ICT, biotechnology, nanotechnology as well as to creative industries is predicted. Also, this is a period of economic challenges demanding expansion into new markets and innovating activities, which is linked to a different approach to talent in companies.

In this context, interaction of creativity, business, management and culture is relevant. Here it is also necessary to consider the role of new technologies, the process of globalization and a trend towards an increasing interaction in redefining the relations between producers and service providers on the one hand, and consumers on the other, while acknowledging the specific aspects of the audience in certain creative industries. Cultural exchange and networking is intensified. From consumerism which implies the importance of quantity and frequency in the domain of consumption, an ever greater role is now played by individual choice and participation, which is especially prominent in the case of creative industries, and inherent in the "age of the Web 2.0" and the behaviour of the "active consumer" linked to the concept of a prosumer. For managers, creative products and services are important in relation to value adding. The creative economy is part of the global economy which is of increasing importance.

\section{Implications of the new concept of creative industries on management}

In current economic and business conditions the development of creative industries is challenging. This is particularly important from the viewpoint of market potential, innovation, possibility of increasing employment, and export growth. 
Creativity in the broader sense is specified as the ability to create something new. It can be described in management as generating new and useful ideas for an organization (Muñoz-Doyague, González-Álvarez \& Nieto, 2008). This means that part of the value should be realized in the future as the result of creativity. Creativity in the final instance is important from the perspective of achieving company goals. Today the promotion of creative management as a tool for achieving sustainable competitive advantages in global environment is in focus (Sofronijević, Milićević \& llić, 2012).

The connection between innovation, creativity and management is also relevant. In creative industries, managers must make business decisions taking into consideration the fact that the symbolic value of the product is becoming increasingly important. Creativity can be considered as an economic activity when it produces a certain idea with economic implications or a tradeable product, but it is difficult to determine the transition from idea to product, from the abstract to the practical (Howkins, 2002).

Creative industries incorporate visual arts (including museums), performing arts, libraries, archives, archaeological sites, film, video, radio, television production, video games, music production, publishing, print and digital media, advertising, architectural services, design (product design, graphic design, fashion design, toy product design), the entertainment industry, multimedia and software. The growth of creative services most often relate to architecture, advertising, design, creative research and development, cultural services, digital services. Particularly owing to the expansion of the ICT sector, there are new possibilities and challenges for the development of creative industries. In recent years the experience economy has developed, this creates an experience along with the consuming of physical products and the use of services by the consumers or by the audience. This is typical of exhibitions in museums and galleries, concerts, performances, archaeological sites, festivals. A greater focus of managers is directed to customer relation management, to product customization and personalization. This above all refers to marketing activities, including the artwork and antiques market, artisan crafts, design, software, entertainment, tourism, sport. The expansion of creative industries in the process of overcoming the global economic crisis is also present, which is especially manifested through forming of creative clusters throughout the world. For managers, the increase in the importance of creativity as a source of competitive advantage on the global scale is significant.

For the first time creative industries were specified as part of the changeable economic landscape of Great Britain. The defining of creative industries as activities whose origin is linked with individual creativity, skill and talent, and with the potential for creating wealth and new jobs by generating and exploiting intellectual property was influential. In the first Mapping document from 1998, the following industries were designated as creative: advertising, art and the antiques market, architecture, crafts, design (especially fashion design), film and video, interactive leisure software (electronic games), music, performing arts, publishing, software and computer services, television and radio (Mapping Creative Industries: A Toolkit, 2010). This list of creative industries is used by many countries in the world as the basis for developing their own classification. International organizations are also relevant in this area, and their reports have shown creative industries as having a significant percentage of world trade, with a high average export growth rate at the beginning of the new millennium.

We should also consider the broader dimensions of creative industries. They add value to other activities, above all through design, advertising and branding, and are also important for employment, especially for educated, creative and talented people In 2006, the European Union (EU) published the KEA Report on creative industries which stressed the difficulties of certain analyses of these industries due to the problem in defining their scope and especially in comparing data (KEA, European Affairs, 2006). Cultural and creative industries from the viewpoint of the EU include architecture, archives and libraries, artisan crafts, the audiovisual field (film, television, video games and multimedia), cultural heritage, design, festivals, music, performing arts, publishing, radio and visual arts (http://ec.europa.eu). They represent one of the most dynamic sectors in the EU and are vital for confirmation of cultural diversity. They employ a million people, have a considerable share in the GDP and are growing faster than the rest of the economy. However, firms in these industries, especially small and medium sized enterprises often face difficulties in realizing their full potential. This was intensified in the conditions of a global economic crisis. The European Creative Industries Alliance should encourage the forming of clusters and their linking, develop activities related to support business and innovation, and facilitate access to funding.

The classification of creative industries into 3 groups originated in Singapore: (1) art and culture, (2) design and (3) media. Art and culture include photography, the visual arts, trade in artworks and antiques; design includes software, advertising, architecture, interior design, graphic design, industrial design, fashion; while 
media include publishing, TV and radio, digital media, film and video. In Sweden, the focus is on the experience economy, which also includes the restaurant business. The Netherlands is characterized by a creative business services category which incorporates landscape architecture, as well as creative ICT - games, new media and urban development. In India, known for its emerging economy, creative industries include products and services related to lifestyle, more particularly yoga and ayurvedic medicine.

In many countries creative industries are dominated by small firms which could be the result of a creative business venture, focused on market niches, and which usually face high fixed costs, as well as large, often multinational companies realizing economies of scale and with wide distribution of affirmed creative products. Many costs of creative activities at the same time have the character of fixed and sunk costs, which represent a newer category linked to costs necessary for a certain activity, but which cannot be recovered or reversed if this activity ceases. Examples are high fixed costs of theatre production (Caves, 2012).

This indicates the importance of non-price factors of competitiveness. Besides, managers' creativity is a vital factor in the process of formulating and realizing competitive strategies. The wheel of creative strategy points to ways in which creativity influences the realization of competitive goals of the company (Figure 1). Besides product development, this includes a strong brand, motivated human resources and managers that encourage creativity.

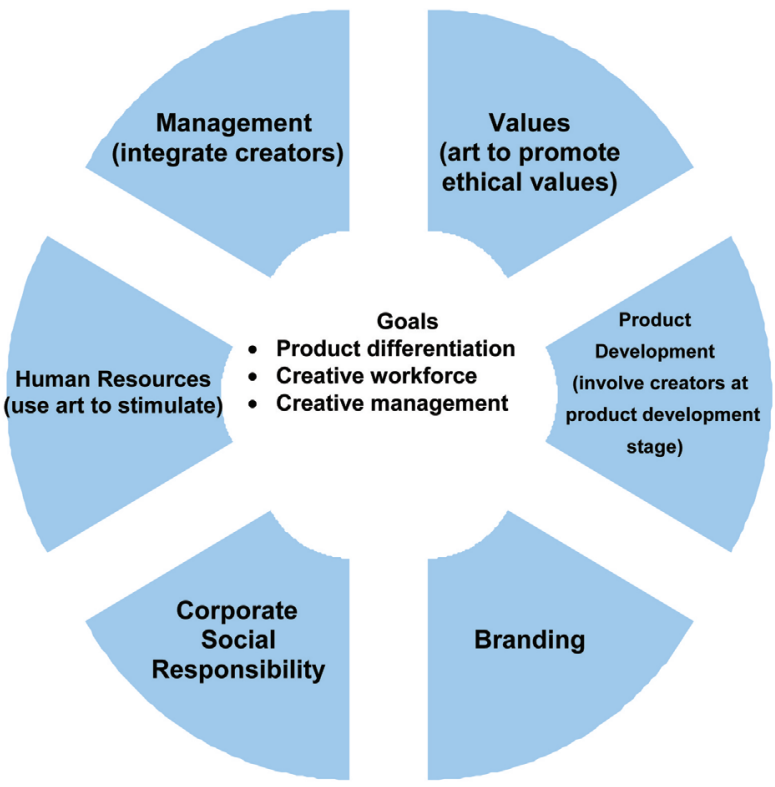

Figure 1: The Wheel of Creative Strategy Source: KEA, European Affairs, 2009, p. 53

All over the world companies have a varied offering in the sphere of creative products and services. The affirmation of the Renaissance model in management development has become a current topic of discussion. Designers are included more often in managerial teams. Also, companies are now hiring creative people, especially artists to spend time with their employees, affirming aesthetic values, which are becoming ever more important for many buyers of their products. On a global scale, success was achieved with products bearing the names of famous artists, and a typical example is the Picasso car of the French company Citroën which launched the slogan "Creative technologié" (www.citroen.com) as well as Mozartkugel which are among the special offer of the city of Salzburg as part of their developed cultural tourism famous for the Salzburg Festival primarily focused on classical music. Many companies encourage the work of artists, especially in fine arts, such as the successful example of the collection of contemporary Serbian art of the company Telenor as part of their "investing in creativity"(www.telenor.rs). A specific link between business, artists and branding is established, and now more and more photograph prints of artists, philosophers and artworks are exhibited on mass consumer goods (especially on clothes, leather goods and furniture). On the other hand, artists find inspiration in mass consumer goods, and a prime example was American artist $A$. Warhol. In performing arts there is cooperation with companies from different business fields, such as the 
strategic partnership of the National Theatre from Belgrade and the Telenor foundation, as well as of the Belgrade Philharmonic foundation and the Hemofarm foundation (www.bgf.rs). Artworks are exhibited throughout the business world and have become part of the interior design of modern production and service firms, and this is relevant for both employees and buyers who, besides consuming products and services, now also expect an experience.

\section{The creative industries market and business success}

Intangible, creative, symbolic goods entail ideas, experiences, perception, images, media content, software, design solutions, information, and a variety of services. In practice, a creative product refers to a tangible product or service which represents the result of creative activities and has recognizable economic value (Howkins, 2002). As a symbol of creative economy, particularly in focus is often art with its business models and specific form of supply, demand, valuation of artworks and manner of setting prices on the art market. In the modern turbulent global environment, with a shortened lifecycle of products and services, creativity is particularly important in the sphere of research and development activities, design, product branding, as well as in the domain of management, especially through a creative approach to marketing and strategic changes at the level of companies and business networks. Also characteristic is the new relationship between business and art on the one hand and science and art, on the other, often leading to new products and services. Creativity in business is manifested in several areas - generating ideas, development of products and services, use of imagination, creating innovation, formulating strategies, increasing competitiveness, cost control, acquiring new knowledge, marketing and managing intellectual capital. Creative organizations are the result of creative management. Business itself is becoming more and more dependent on creativity in the $21^{\text {st }}$ century. The importance of digital products of creative industries such as software, electronic books and magazines, digital photography, film industry products, music files and the results of artistic activities in new digital art is becoming evident. Digital processes and the electronic market are linked with the relatively low costs of digital technologies. One of the most recent developments is mobile digital art, especially using the iPad and iPhone as creative tools.

Creative economy as a concept links economy, culture, management and technologies in an environment dominated by visualization. Some creative industries today are among the fastest growing sectors of the world economy, and companies in these industries realize considerable revenues and profit based on successful sales of their products and services. The creative economy consists of transactions related to creative products that can have two complementary values: the value of the intangible (in many cases including intellectual property) and the value of the physical carrier or platform (if it exists). Creativity itself cannot be quantified, but the number of creative products can. The creative equation states that the creative economy $(C E)$ is equivalent to the value of creative products $(C P)$ multiplied by the number of transactions $(T)$ (Howkins, 2002). This means that

$$
C E=C P x T
$$

Aspects of the creative economy can be shown through the culture cycle model (Figure 2). It is based on the conceptualization of the way in which activities in business practice occur in relation to production and distribution of cultural goods and services. In the culture cycle model there are 6 successive phases from creation to consumption which often entails participation of the consumer. There are also feedback processes, and consumption inspires the designing of new products. The network structure of the model focuses on new production which is facilitated owing to the development of information and communication technologies. 


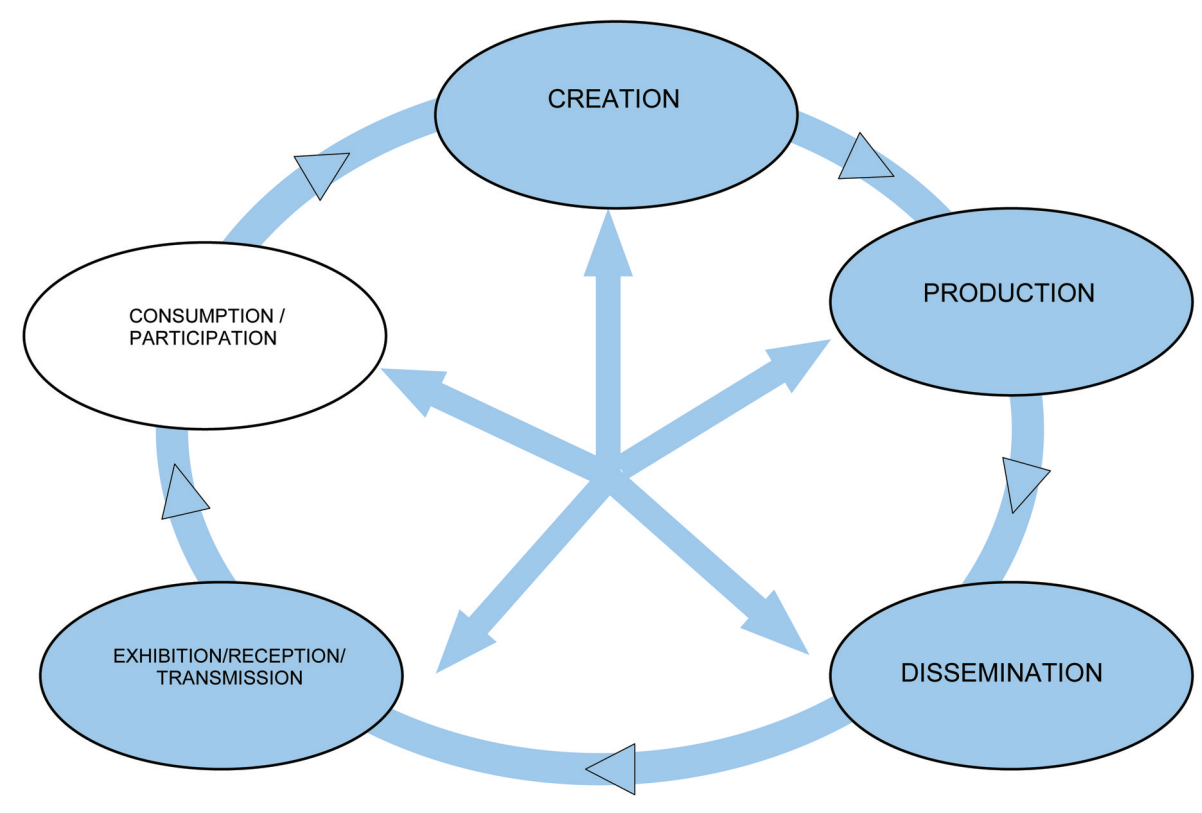

Figure 2. Culture Cycle Model Source: The 2009 UNESCO Framework for Cultural Statistics, p.20

In the information economy, human attention is a rare resource of creative industries. It is important to consider the dynamics of attention - the manner in which it is attracted and retained. This issue is especially relevant for managers in showing them how to convert attention into commercial value when there are many contents of creative industries being offered simultaneously (Hartley, J. et al., 2003). The allocation of limited attention of service users i.e. the audience for creative offers is especially important with changes related to digital media, such as social network platforms.

Competition is considered desirable on the creative industries market from the aspect of their vitality, efficiency and introduction of progress through presenting new ideas. Consumers certainly benefit most from the competitive market structure with lower prices and greater choice. Competitiveness can be compatible with cooperation, as cooperative strategies are realized to successfully compete on the creative industries market for "votes" of consumers regardless of whether they "vote" with money or attention, while acknowledging the fact that often there is general unpredictability regarding success and failure of a business venture in creative industries. In the focus is the consumer of creative products, the service user or experience consumer, and often the issue is the co-creation in the context of inclusion in a network. We must consider technological convergence which implies that digitalization facilitates conversion and distribution of content through multiple formats and platforms. From business perspective the forming of strategic alliances and conglomerates in the domain of media and communication is important. An illustrative example is the Walt Disney Company with film and television production, music, video, publishing, travel, theme parks. It is one of the biggest world media conglomerates with its five business segments: media networks, parks and resorts, studio entertainment, consumer products and interactive media (www.thewaltdisneycompany.com). In this sense one can view the development of the company Google Inc. as a new conglomerate (www.google.com).

The international project Google Books was initiated by the company Google Inc., and a large number of participants in the project are libraries from different countries offering contents from their funds to be digitalized. Online access to this digital content means that this project greatly contributes to the development of creative industries. At the global level there is also the Google Art Project realized by the Google Inc. Company in cooperation with famous world museums (www.googleartproject.com). It offers, with respect to the unique experience a real-life visit to the museum, the possibility of a virtual tour of many world museums.

Large exhibitions are, in conditions of increasing digitalization, important from the aspect of culture and business results. Tables 1 and 2 show 10 of the biggest world exhibitions by number of visitors, which besides the spiritual, aesthetic experience or education bring considerable revenue from ticket sales, as well 
as the sale of prints, artwork replicas, exhibition souvenirs, books, DVDs and other products, and have an impact on other sectors (tourism, hospitality, transport). Analysis shows that, besides painters, these top exhibitions include cultural heritage and fashion designers (Chanel and Alexander McQueen at the Metropolitan Museum of Modern Art - MOMA in New York). It is interesting that the most visited exhibition in 2011 was held at the Centro Cultural Banco do Brasil which is a former bank building.

Table 1: Top 10 exhibitions that recorded the most admissions in the world, 2005

\begin{tabular}{|c|c|c|c|c|}
\hline & Admissions & Exhibition & Venue & City \\
\hline 1 & 937,613 & $\begin{array}{l}\text { Toutankhamon et l'âge d'or des } \\
\text { Pharaons }\end{array}$ & Lacma & Los Angeles \\
\hline 2 & 866,812 & Toutankhamon et la vallée des rois & $\begin{array}{l}\text { Ausstellungshalle der } \\
\text { Bundesrepublik }\end{array}$ & Bonn \\
\hline 3 & 699,486 & Pharaon & Institut du Monde Arabe & Paris \\
\hline 4 & 621,814 & $\begin{array}{l}\text { Chefs d'oeuvre français du XIXème } \\
\text { siècle du Musée du Louvre }\end{array}$ & Musée d'Art de Yokohama & Yokohama \\
\hline 5 & 607,699 & L'Empire Aztèque & Guggenheim Museum & Bilbao \\
\hline 6 & 518,307 & Van Gogh dans son contexte & $\begin{array}{l}\text { Musée National d'Art } \\
\text { Moderne }\end{array}$ & Tokyo \\
\hline 7 & 501,601 & Turner Whistler Monet & $\begin{array}{c}\text { Galeries Nationales du Grand } \\
\text { Palais }\end{array}$ & Paris \\
\hline 8 & 463,603 & Chanel & MOMA & New York \\
\hline 9 & 459,972 & Vincent Van Gogh Les dessins & MOMA & New York \\
\hline 10 & 440,564 & Monet la Scène et les Nénuphars & Museo Di Santa Giulia & Brescia \\
\hline
\end{tabular}

Source: Journal des Arts, numéro 235, 14-27 avril 2006, according to KEA, European Affairs 2006, p. 153

Table 2: Top 10 exhibitions that recorded the most admissions (daily) in the world, 2011

\begin{tabular}{|c|c|c|c|c|}
\hline & $\begin{array}{l}\text { Admissions } \\
\text { (Daily) }\end{array}$ & Exhibition & Venue & City \\
\hline 1 & 9,677 & The Magical World of Escher & $\begin{array}{c}\text { Centro Cultural Banco do } \\
\text { Brasil }\end{array}$ & Rio \\
\hline 2 & 9,108 & $\begin{array}{l}\text { Kukai's World: the Arts of } \\
\text { Esoteric Buddhism }\end{array}$ & Tokyo National Museum & Tokyo \\
\hline 3 & 8,828 & Landscape Reunited & National Palace Museum & Taipei \\
\hline 4 & 8,025 & $\begin{array}{l}\text { Alexander McQueen: } \\
\text { Savage Beauty }\end{array}$ & $\begin{array}{c}\text { Metropolitan Museum of } \\
\text { Art }\end{array}$ & New York \\
\hline 5 & 7,609 & $\begin{array}{c}\text { Claude Monet } \\
(1840-1926)\end{array}$ & Grand Palais & Paris \\
\hline 6 & 7,304 & Photoquai & Musée Quai Branly & Paris \\
\hline 7 & 6,991 & Mariko Mori: Oneness & $\begin{array}{c}\text { Centro Cultural Banco } \\
\text { do Brasil }\end{array}$ & Rio \\
\hline 8 & 6,967 & Monumenta: Anish Kapoor & Grand Palais & Paris \\
\hline 9 & 6,934 & Laurie Anderson & $\begin{array}{c}\text { Centro Cultural Banco } \\
\text { do Brasil }\end{array}$ & Rio \\
\hline 10 & 6,649 & $\begin{array}{c}\text { The Prado Museum at the } \\
\text { Hermitage }\end{array}$ & State Hermitage Museum & St Petersburg \\
\hline
\end{tabular}

Source: (Pes \& Sharpe, p. 35, 2012) - The Art Newspaper, No. 234, April 2012, p.35 
In creative industries there are many commercial intermediaries - art galleries in cities with a developed market for artworks. Some galleries have achieved business success by supporting new art styles that have later become globally recognized. So, for example, the Betty Parsons gallery in New York affirmed artists of abstract expressionism, the gallery Leo Castelli from New York introduced works of pop art onto the market, while the gallery Denise René from Paris introduced op-art works, and the gallery Virginia Dwan championed the art production of minimalist painters, while the gallery Mary Boone successfully launched figurative painters as a reaction to minimalist art which points to the importance and dynamics of this market (Caves, 2012), (www.castelligallery.com), (www.deniserene.com). Viewed as a whole, the role of marketing intermediaries for artists or teams of artists in the sphere of visual arts, literature, film, theatre, classical, pop and rock music is important. Some international musical and film stars have incomes which can be compared to the revenues of large companies. On the other hand, effective management is present in many companies belonging to creative industries, such as media corporations, disc recording companies, film studios, publishing companies, newspaper publishers, and fashion designer companies.

An illustrative example from the market aspect is London, which many consider the capital of creativity in publishing, show-business, media, TV production, and cultural tourism. In Great Britain and in the world many famous persons from creative industries have achieved success in a business sense. Noteworthy examples include the famous world band The Beatles in music production, especially in the discography and the writer J.K. Rowling in publishing with her Harry Potter books which have sold in over 400 million copies on the world market, and as of 2012 are available through the online store The Pottermore. J.K. Rowling was in the "billionaires club", according to the Forbes list for 2011, and The Pottermore store has recorded sales of over 4 million USD in the first month of business (www.forbes.com/profile/joanne-jk-rowling/).

One relevant indicator for creative industries refers to export results. Table 3 shows foreign trade of the EU in cultural goods in 2009, expressed in millions of EUR which covers exports and imports of tangible goods, and does not include licenses and copyrights. We can conclude that for most of the cultural goods there is a surplus of export over import, as is shown through the EXP/IMP ratio.

Table 3: EU-27 external trade in cultural goods in million EUR, 2009

\begin{tabular}{|c|c|c|c|c|}
\hline Cultural goods & Exports & Imports & Balance & $\begin{array}{c}\text { Ratio } \\
\text { EXP/IMP }\end{array}$ \\
\hline Books & 2221 & 1651 & 570 & 1.3 \\
\hline $\begin{array}{c}\text { Newspapers, journals } \\
\text { and periodicals }\end{array}$ & 718 & 194 & 524 & 3.7 \\
\hline CDs & 153 & 65 & 88 & 2.4 \\
\hline DVDs & 421 & 146 & 275 & 2.9 \\
\hline Musical instruments - Pianos & 64 & 87 & -23 & 0.7 \\
\hline Paintings & 1770 & 1181 & 589 & 1.5 \\
\hline Sculptures & 574 & 243 & 332 & 2.4 \\
\hline Antiques & 471 & 244 & 227 & 1.9 \\
\hline
\end{tabular}

Source: EUROSTAT Cultural Statistics 2011, p. 117

Certain cities in the EU countries, as well as in other countries have become centres of creative industries in a global environment. In recent years, with the affirmation of the concept of creative industries, many countries and large cities have become aware of their importance in a business sense. In Barcelona, Vienna, Amsterdam, Helsinki, Hong Kong creative industries are undergoing a planned development (Hagoort \& Kooyman, 2010). It can be concluded that creative industries today have a global impact.

It is important to emphasize that, with the acknowledgment of the importance of input, especially of creative ideas, business criteria in creative industries focus on output, outcome and results. Return on investment $(R O I)$ has become a key term in investment in the domain of creative industries. Particularly important is advertising as the typical activity of the late $20^{\text {th }}$ and early $21^{\text {st }}$ centuries which includes consumer research, managing the marketing activities of clients, making a communication plan, targeting consumers, creating advertising, promotion, PR campaigns, media planning. Also important is interdisciplinary art practice which results in innovative creative products and services. 
We can compare the European tradition of public culture and cultural institutions with to a larger extent individualistic tradition and the entrepreneurial spirit of the USA aimed at successful realization of products and services on the market. The Silicon Valley in California is the symbol of the model of a geographical creative cluster, especially important from the aspect of software as the product of creative industries placed on the global market. The concept of creative cities is being intensively developed in Europe (Greater London, Am-Brus-Twerp) and in Asia (the Shanghai-Beijing corridor, the Bangalore - Mumbai area in India) (Montgomery, 2010).

Links have become important between places where the firm is located, especially regarding creative clusters and creativity, not only for collective but also in the case of individual creativity. Also relevant is the empirical research which shows how in selected creative sectors: (1) digital design (including website design and the design of the visual elements of interactive software) and (2) craft metalwork (including design and manufacture of metal objects which have aesthetic value as a major element of their value-added) perceived attributes of the location influence inspiration in the creative process (Drake, 2003).

Creative industries are also developed in Nigeria, characterized by a quickly growing market and the process of business diversification. Also present is the tendency towards creating global partnerships in the creative sector. Production of films in the world is typical of Hollywood in the USA, Bollywood in Mumbai, India (for mass audiences throughout Asia and Africa and other markets) as well as Nollywood in Nigeria where the film industry has developed to a great extent owing to digital technologies. Nigerian music and films are successfully placed on markets throughout Africa (Nollywood dreams, Nigeria's Film Industry, 2006 - The Economist).

In China the evolution of new business models, the impact of state regulations, social networks, entrepreneurship of consumers have in recent years become important driving forces in production and commercialization of cultural goods. Important segments of creative industries are Chinese film, music and fashion industry (Montgomery, 2010). In addition the slogan 'Created in China' has become current implying the development of its own creative sector, with encouragement of domestic consumption on the great market, but also of export of Chinese cultural goods, media production and other products of creative industries with the development of branding. In Australia special attention is paid to media in the digital and interactive era (Montgomery, 2010).

\section{Conslusion}

The affirmation of new business models in creative industries is a current issue. On the side of culture are certainly creativity and talent, with the participation of not just experts and artists, but also consumers in the cases of co-creation, and on the economic and managerial side are innovation and development in the new economy, as well as affirmation of creative management, with the tendency towards greater application of methods and techniques of contemporary management in creative industries. Information and communication technologies are essential in developing creative industries, above all new media platforms. The affirmation of the market approach, while acknowledging intangible aspects, ideas, inspiration or uniqueness in certain segments of creative industries, i.e. artistic and creative components, is of particular importance. This further leads to a change in the perception of culture as a mere consumer in a social framework, towards a sector that "earns", i.e., contributes to the development of the new economy. It is necessary to acknowledge the fact that cultural industries on a global scale have experienced dynamic growth and have had a multiplier effects on other commercial sectors. Also evident is the increasing entrepreneurial initiative and the presence of start-up companies, micro businesses and individual traders in artworks. Digital technologies have enabled the dissemination of creativity throughout the world and initiated the development of online creativity. In the future period there will be more and more challenges for creative industries from the aspect of business, i.e., new business opportunities.

Many segments of creative industries are commercially oriented. Also, creative industries bring new ideas, change in the way of thinking and lifestyle and are suitable by their nature for adapting to the needs and demands of consumers in the process of customization of products and services. They can considerably contribute to increasing competitiveness of companies and the economies in the global market. Creative industries today represent a dynamic emerging sector of the world trade.

The growth of the economy of attention is especially linked to social networks with the parallel existence of a monetary economy. People realize the importance of attention, the economy of signals is being developed along with, on the other hand, the existence of monetary value and development of a co-creative culture. 


\section{REFERENCES}

[1] Caves, R. (2012). Creative Industries, Contacts Between Arts\&Commerce. Los Angeles, London, New Delhi, Singapore, Washington DC.

[2] Drake, G. (2003). This place gives me space: Place and creativity in the creative industries, Geoforum, 34, 511-524.

[3] http://ec.europa.eu/culture/our-policy-development/cultural-and-creative-industries_en.htm

[4] Eurostat. (2011). Cultural Statistics, Luxembourg: Publications Office of the European Union

[5] Hagoort, G. \& Kooyman, R. (2010). Creative Industries: Colourful Fabric in Multiple Dimensions. Delft: Eburon Publishers.

[6] Hartley, J. (2005). Creative Industries. Malden, Oxford, Carlton: Wiley-Blackwell.

[7] Hartley, J., Potts, J., Cunningham, S., Flew, T., Keane M. \& Banks, J. (2013). Key Concepts in Creative Industries. London, Thousand Oaks California, New Delhi, Singapore: Sage Publications Ltd.

[8] Howkins, J. (2002). The Creative Economy, How People Make Money from Ideas. Penguin Books.

[9] KEA, European Affairs. (2006). The Economy of Culture in Europe - A Study prepared for the European Commission, Directorate-General for Education and Culture.

[10] KEA, European Affairs. (2009). The Impact of Culture on Creativity - A Study prepared for the European Commission, Directorate-General for Education and Culture.

[11] Mapping Creative Industries: A Toolkit, (2010). London: British Council.

[12] Montgomery, L. (2010). China's Creative Industries: Copyright, Social Network Markets and the Business of Culture in a Digital Age. Cheltenham: Edward Elgar Publishing Limited.

[13] Muñoz-Doyague, M. F. N. González-Álvarez \& M. Nieto (2008). An examination of individual factors and employees' creativity: the case of Spain. Creativity Research Journal, 20: 21-33.

[14] Nolywood dreams, Nigeria's Film Industry. (2006). The Economist, July 27th.

[15] Pes, J \& Sharpe E. (2012) Exhibition \& Museum Attendance Figures 2011. The Art newspaper, No. 234, April.

[16] Sofronijević A., Milićević V. \& Ilić B. (2012). Creative Management, Intellectual Capital and the Race Against the Machine, Advances in Business-Related Scientific Research Conference - ABSRC 2012, ABSRC 2012 Conference Proceedings, Olbia, Italy, September 5 - 7, 2012.

[17] The 2009 UNESCO Framework for Cultural Statistics (FCS). (2009). Montreal: UNESCO Institute for Statistics.

[18] http://www.bgf.rs

[19] http://www.castelligallery.com

[20] http://www.citroen.com

[21] http://www.deniserene.com

[22 http://www.forbes.com/profile/joanne-jk-rowling/

[23] http://www.google.com

[24] http://www.googleartproject.com

[25] http://www.telenor.rs

[26] http://www.thewaltdisneycompany.com 


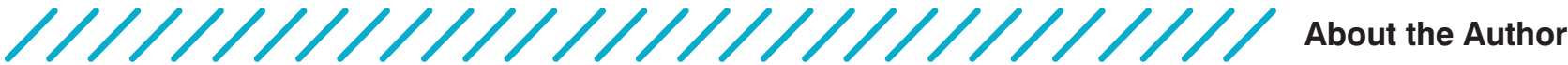
Vesna Milićević
University of Belgrade, Faculty of Organizational Sciences
milicevic.vesna@fon.bg.ac.rs

Dr. Vesna Milićević is a professor at the Faculty of Organizational Sciences of the University of Belgrade where she teaches courses in the areas of economics, management and international business. She is author or co-author of a number of monographs, textbooks and articles in national and international scientific and professional journals. Vesna Milićević is an elected member of the Scientific Society of Economists of Serbia. She has participated in strategic scientific \& research projects and in projects and management training in companies.

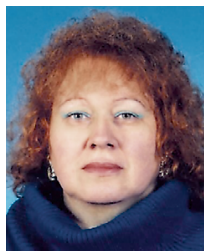

Bojan Ilić University of Belgrade, Faculty of Organizational Sciences ilic.bojan@fon.bg.ac.rs

Dr. Bojan Ilić is a professor at the Faculty of Organizational Sciences of the University of Belgrade, and he is both an economist and engineer of information systems. He received his MSc and PhD degrees at the Faculty of Organizational Sciences in Belgrade. He is the author of two

monographs, co-author of several books. He has published many scientific and professional papers in the area of economy, IT and management in the country and abroad. Bojan llić is an elected member of the Scientific Society of Economists of Serbia.

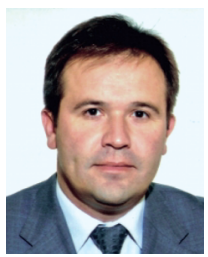

Adam Sofronijević University of Belgrade, University Library Svetozar Marković sofronijevic@unilib.bg.ac.rs

Adam Sofronijević is a management engineer - master and works at the University Library "Svetozar Marković" of the University of Belgrade. He has written chapters in several scientific monographs and a large number of scientific and professional papers in the fields of librarianship, management and IT in domestic and foreign journals. He participates in activities of the Association of European Research Libraries. Adam Sofronijević has many years of managerial experience in

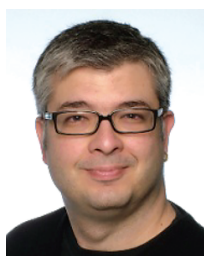
the areas of creative industries and digitization. 